\title{
Chapter 1 \\ Spaces of Solidarity and Spaces of Exception: Migration and Membership During Pandemic Times
}

\author{
Anna Triandafyllidou
}

\subsection{Introduction}

During 2020, as the coronavirus pandemic spread around the world, we have witnessed countries making unprecedented decisions, restricting international travel and closing borders but also chartering flights to bring in migrant workers employed in essential sectors. While important (internal) travel restrictions were first implemented by China in late February 2020 on the Chinese New Year holiday, the relevance of borders in relation to controlling the pandemic became internationally visible when the United States banned EU citizens from entering the country on 14 March 2020 as Covid-19 cases and victims sharply rose in Italy and a number of other European countries. A sweeping closure of the EU external borders to all nonEU citizens was announced on 17 March 2020 - a rare occasion where EU citizenship had a tangible effect on all EU citizens' livelihoods without being mediated by their national citizenship. That closure confirmed that EU citizens and their national governments felt they were closer together and in solidarity and interdependence under this pandemic although intra-EU border closures followed. Indeed, March 2020 saw the closure of borders between countries with very long and strong socioeconomic and political ties such as Canada and the US (a closure that is still effective at the time of writing in November 2020), or member states of the European Union with one another. Regional trade and migration within west Africa were also interrupted abruptly when, for instance, Nigeria closed its borders on 23 March after recording its first death from the virus. And while it was initially hoped that the summer of 2021 will bring not only temporary relief but also a way out of the pandemic, it has since become clear that 2020-2021 will be marked with at least selective border closures and migration and mobility restrictions. The wider impact of the pandemic on society and the economy will be long lasting and global.

\footnotetext{
A. Triandafyllidou $(\square)$

Faculty of Arts, Department of Sociology, Ryerson University, Toronto, Ontario, Canada

e-mail: anna.triandafyllidou@ ryerson.ca
} 
The concern that travellers increase the risk of Covid-19 contagion was and still is legitimate. At the same time, border closures did not keep 'everyone' out, only those who were non-citizens or non-permanent residents. In some countries, like Canada, exceptions were made for temporary residents who effectively live in the country. Many EU countries (including, for instance, Spain, Portugal, Poland, and Germany) implemented blanket extensions of stay permits for all foreigners during spring 2020 to avoid people losing their legal status under the lockdown (EMN, 2020a). Similar measures were taken in Canada, Chile, Israel, and New Zealand, while Italy implemented a regularisation program with a view of providing status to illegally staying aliens working in agriculture and the care sector. Some countries implemented different facilitation procedures like allowing for online renewals of permits, as in the Netherlands, or automatically renewing the status of people who had lost it during the pandemic, as happened in Canada, until the end of 2020, to give them more time to gather necessary documents or find a new job or both (ibid.).

The pandemic border closures not only raised important questions about membership but also left many migrants stranded at destination countries, at origin or also, for some, while in transit. People found themselves unable to go back to their countries of origin as international transport systems came to a halt. Some (as happened in Japan for legally staying foreign nationals) were not allowed entry back to their country of residence even if they had lived there for the previous ten years (Shakuto \& Baldari, 2020). Some who were ready to emigrate, had a new job and a new life waiting for them at a new country, were left stranded, waiting for borders to reopen to foreigners (Triandafyllidou \& Nalbandian, 2020). And yet others, those more vulnerable, like asylum seekers or migrant low skill workers (e.g. domestic or construction workers) found themselves locked up in dormitories (as in Singapore or the UAE) or refugee camps (as in Greece) (see Molnar Chap. 3, in this volume). By contrast, those migrants engaged in 'essential' or 'key' work sectors, like health and care systems or the agri-food sector benefitted from special arrangements so that they could reach destination countries to work and ensure that there was no disruption to such essential services that regular residents or citizens rely on (Palumbo \& Corrado, 2020b; and also Palumbo and Corrado Chap. 8, in this volume). Other low skilled or semi-skilled migrant workers, however, faced forced returns to their country of origin. Qatari authorities deported Nepali citizens back to Nepal, while the UAE threatened south Asian countries that future labour migration would be jeopardised if they refused to take back their citizens (Shivakoti, 2020). Oftentimes departing workers lost salaries not yet paid or had to leave their belongings behind.

States have adopted a mixed 'citizens first' approach in terms of public health protection and restriction of mobility enforcing territorial border closures. At the same time, as the pandemic has unfolded since early 2020, states are providing protection to both temporary residents and people with 'pending' status (waiting for regularisation or visa renewal) to avoid their finding themselves in a situation of irregularity under the pandemic emergency. The pandemic border closures have indeed raised numerous complex legal, political, and ultimately symbolic questions about what community, solidarity, belonging, and civic responsibility mean. The 
crisis has shown with renewed emphasis that citizenship is a complex and multifaceted concept and reality, and that there are several alternatives of community and membership that we need to consider that may not necessarily be tied to the legal relationship between the individual and the state expressed in the classical notion of national citizenship (Baubock, 2018). The exceptional character of the Covid-19 emergency has both reinforced the importance of citizenship as a priority marker of who belongs and who is to be allowed access to the country or access to emergency benefits during the pandemic crisis. At the same time the emergency has pushed the boundaries of what I will call 'effective membership' further to include everyone present in the territory. We may even argue that the pandemic emergency has given rise to an alternative mode of membership that could be termed jus domicilii (Stavilă, 2013) and is based on effective presence in the territory of the state.

This chapter discusses the contradictions that the pandemic has exposed regarding migration at two levels: first at the level of membership and belonging, and second at the level of migration governance. Border closures and selective openings have raised important questions about the notion of membership, solidarity, and responsibility, asking whether this pandemic opens up possibilities for a new understanding of citizenship or of membership to a political community that is postnational. Second the pandemic has subverted our dominant understandings of desired, valued, and unwanted migration as those migrant workers previously considered 'disposable' like farmworkers, domestic and care workers, courier employees, and platform workers suddenly became 'frontline' essential workers, much needed, while the previously valued and desired highly skilled migrants have been temporarily neglected (Nalbandian \& Triandafyllidou, 2020a, b). After posing these two sets of questions and highlighting what could be new and innovative answers, this chapter presents the contents of the book and how they seek to answer these two questions of how we should understand migration and membership in pandemic times and how we should (re-)organise the governance of migration during and after the pandemic.

\subsection{Membership, Responsibility, and Solidarity in Pandemic Times}

The Covid-19 virus has proven to be truly transnational, moving fast across not only national borders but also across ethnic communities, social classes, cities, and small towns, ignoring territorial borders and sovereign governments. Despite this transnational character, the virus has pointed to how much countries, governments, and even health authorities are interdependent under the emergency, yet states reacted initially by prioritising citizens. Weighing their obligations towards solidarity and protection of citizens has led to border closures - the most notorious of which was US President Donald Trump's sudden closure of the US border to all EU citizens in March 2020. Under pandemic circumstances, citizens have been allowed to return 
to their own country but 'others' - notably temporary residents, their family members, international students, and visitors or distant family members of citizens have been banned from entry. The rationale of these decisions has relied on a balancing act between a health risk, on one hand, and membership and solidarity, on the other. Those who do not belong fully to the nation-state need to stay out, at least temporarily. The border closure has also affected those seeking international protection. Their right to apply for asylum was temporarily de facto suspended in many countries such as Canada (for people coming from the US) or Greece (mostly for those crossing via Turkey). One might argue that there was a trade-off between the reasons that favour admission (solidarity toward citizens, obligations toward refugees, immigration objectives) and the possible health risks that come from admitting people (citizens or others) arriving from abroad. There seemed to be, in other words, a cost-benefit analysis where the benefits of protection to refugees was simply discounted.

The rationale of solidarity and interdependence and the trade-off between protecting citizens vs assisting aliens under the pandemic emergency merits some further discussion though. There are two different facets of this argument; one concerns the extent to which citizens have a priority over 'others', even if those others are temporary residents of the country and hence partly members of the political community. While in theory the answer to this argument may be straightforward, in practice this is less the case as one wonders how one should classify temporary residents (under different legal statuses) who effectively have strong ties with their 'host' country in the sense that they live, work, pay taxes, contribute to the community, send their kids to school, and participate in public life even if they do not have political rights. The second facet introduced a novel element as it concerns the level of civic responsibility that we are entitled to expect from citizens who should behave in a way that protects their fellow citizens. But then how do we account for temporary residents who make a special civic contribution to the community under the emergency situation, notably through working at essential and risky sectors?

The pandemic and related international border restrictions have emphasized the existence of different layers of membership within each country. Such membership layers distinguishing citizens from residents from aliens are not new and immigration and enforcement policies have played an important role in (re-)constructing imagined communities of 'aliens' (Aleinikoff, 1995; Romero, 1998). The pandemic has pushed the boundaries of these different layers, blurring and redrawing their contours. The emergency has raised important clarification questions: where does the boundary between insiders and outsiders effectively lie and who should be in or out? For instance, should people with temporary status be given exemptions from border restrictions or should they be excluded? What matters most: their effective residence or their immigration status? Similarly, should asylum seekers be included - in respect of the international right to asylum - or should this right be suspended during the pandemic?

We can imagine the effective population of a country as a set of concentric circles (see also Triandafyllidou \& Veikou, 2002): The inner group includes the citizens, those who belong and who have a clear and stable legal relationship with the 
state. The citizens are expected to take priority in terms of protection of their right to life and health, both as regards their protection through reduced international mobility but also through access to the public health or welfare system. At the same time, they are expected to show loyalty and solidarity to fellow citizens, which in the case of the pandemic emergency may include adhering to the guidelines of the authorities or, for instance, restraining from international but also domestic travel with a view to avoid spreading the virus. I will return to this argument a little later.

In immigration countries like Canada or Australia or the US, people accepted as permanent immigrants (e.g. green card holders in the US, so-called PRs in Canada) are treated like citizens for what concerns their socio-economic rights, including for instance access to public health or family reunification rights. In other countries with significant immigrant populations, like Britain or Germany, this status is called 'the right to abode' and is given to people who were initially temporary migrants but acquired long-term resident status. Transnational entities like the European Union create an additional layer of belonging as European citizenship gives EU citizens who live in another member state equal rights with those of the citizens of that country (Bauböck, 2019). Such people who are not citizens but who have an enhanced residence status have been treated under the pandemic like citizens and the pandemic actually has somehow reinforced their belonging to the in-group.

A grey zone between belonging and exclusion has cast its shadow over people with temporary status who have been admitted to a country for a specific period, whether for study or work, and who are likely to be relatively recent arrivals. These have faced significant hardship (Raghuram \& Sondhi, 2020) as the permits of some expired during the lockdowns while others lost their jobs and hence risked losing their status as a result of the pandemic (Wright, 2020). The pandemic though has forced countries to consider what Canada has termed the 'effective residence' of temporary aliens. Hence beyond the issue of citizenship, the pandemic has brought to the fore the notion of 'effective membership'. It forced governments to ask where people live habitually, where they send their kids to school, where they pay taxes or have health coverage. The pandemic pulled this outer circle of transient members of the community into the inner circle of those who effectively live in the country for what concerned border restrictions (from which they were exempted). At the same time these transient members were internally excluded in some countries as they did not have access to emergency unemployment or family benefits (as happened for instance for temporary migrants in Germany and for Syrian refugees in Turkey). While effective membership may thus still seem tentative, the pandemic has raised the question of whether this notion of effective residence can be codified into law. For instance, it could include consular protection if found temporarily abroad under a sudden border closure, or the right to re-unite with second-degree family members such as elderly parents or adult children who may find themselves cut off from extended family during the pandemic restrictions.

While for temporary migrants maybe the dilemmas of border restrictions and service provisions were easier to solve through an inclusive approach, the dilemmas raised by asylum seekers entering a country to seek protection or temporary migrants whose status has expired raised more difficult decisions (Jubilut \& Silva, 2020; 
Godoy \& Bauder, 2020). In the face of increasing contagions and scarce health resources, the balance would clearly tip over prioritising citizens and legal residents. At the same time legal instruments ensuring a general human rights approach like the Canadian Charter of Rights and Freedoms (1982) or the EU Charter of Fundamental Rights (2012) would call for the inclusion of people with precarious status under the protection net of the welfare state and health system. Effectively a review of relevant approaches in the EU and OECD countries has revealed that states have opted for universal coverage particularly regarding access to health services during the pandemic for all people present in their territory regardless of status (EMN, 2020a). The approach there was two-pronged: on one hand, special measures were taken to extend legal status or also regularise those without status and, on the other, health coverage was provided for all with concerted efforts for sharing information in different languages in most EU and OECD countries (EMN, 2020a, 8).

In other countries though like the UAE or Singapore (Molho, 2020) such protections were not afforded to temporary migrant workers who were often locked up in their dormitories to prevent contagion when cases were discovered in their community. Several lost their job and no protection was afforded them; they had to live off their savings while waiting for repatriation flights (see also Rajan and Arokkiaraj, and Sahin Mencutek Chap. 10, in this volume). In addition, those temporary workers or asylum seekers who work in the informal labour market - as is the case for many Syrians in Turkey, Lebanon, or Jordan - the closure of the catering and tourism industries left them without their basic means of subsistence and facing important administrative and linguistic barriers in accessing information about health and sanitation measures.

Asylum seekers posed important dilemmas to countries with long traditions of asylum like EU countries or Canada (George, 2020; Abji et al., 2020; Ellis, 2020). For those inside the country, the approach has been inclusive in affording them protections based on both a human rights perspective and with a view to overall limiting the spread of the virus in the community. However, there were often inhumane practices too (Flynn \& Welsford, 2020): for example, in Greece asylum seekers in the metropolitan area of Athens or the Aegean islands were confined in the reception centres when positive cases were discovered. The crowded living conditions in these centres did not prevent the virus's spread within those communities - while access to healthcare was also limited or non-existent (Molnar \& Braam, 2020) - but priority was given to keeping the virus in the camps and avoiding its spread among the wider community of citizens outside the camp. The border in those cases was recreated within the state, separating those who do not belong from those who belong (see Rosińska and Pellerito Chap. 7, in this volume) within the country's territory. Similar approaches were documented in the US too where detention centres became Covid-19 hotspots (see Boris Chap. 4, in this volume).

Refugee claimants seeking protection by crossing international borders were however the most vulnerable and most exposed category where the pandemic showed how citizenship is prioritised over an international right to asylum or an international respect of human rights. Asylum seekers were pushed back from the 
Canadian border to the US (Ellis, 2020) and prevented from entering Greece from Turkey. While in both cases there are international safe third country agreements in place that could legally justify the move, in both cases those pushed back were in vulnerable conditions and the countries to which they were pushed back are not particularly safe. The Federal Court of Canada in fact ruled on 23 July 2020 that the Canada-US Safe Third Country Agreement (STCA) violates the Canadian Charter of Rights and Freedoms by allowing Canada to send refugee claimants back to the US. Despite these challenges, it was clear that the inner political community of members could not 'afford' to help aliens under the pandemic emergency by allowing them to enter the country. Similar challenges were documented in South Africa (Rugunanan, 2020) and in Singapore and Malaysia (Petcharamasree, 2020).

The pandemic crisis has thus had a polarising effect on our understanding and practice of membership: while it pushed people with temporary status towards the inner circle, it pushed outside those who may have needed protection the most. The pandemic has reproduced borders within the territory of the nation-state by creating closed refugee camps or migrant dormitories and by assigning different mobility rights to citizens/permanent residents and temporary residents. The latter face some discretion at the border if an immigration officer questions the necessity of their presence in the country or they have to prove through additional pieces of evidence that they regularly and effectively reside in the host country.

While many states used their emergency and quarantine laws, and in this sense acted lawfully in exercising delegated legislative authority to declare an exception, they ended up stripping asylum seekers from their right to seek asylum. While a restrictive perspective seeking to evade international obligations in relation to asylum may have been a longer trend, it was exacerbated during the pandemic, leading to the situation that Agamben (2005, see Humphreys, 2006) specified: they exercised their power in deciding on the exception and suspended the juridical order because of the serious crisis threatening the state and its 'legitimate' population. Thus, protecting the most basic rights of asylum claimants to seek refuge is annulled. Border closures such as between Canada and the US to prevent any asylum claimant from entering Canada or on the Greek islands reinforce a sense of national solidarity among citizens and permanent residents and a transnational solidarity among sovereign states, but leave in limbo, in a space of exception, those who are among the most vulnerable populations: notably asylum seekers and irregular migrants seeking entry. They fall into this zone of "active abandonment" that is neither inside nor outside the polity, it is just there at the border (Pinelli, 2018).

The pandemic has exposed further fissures and dilemmas in our understanding of the limits and hierarchies of membership, belonging and solidarity. As it happened in Canada, the US, Germany, Italy, Spain, or Poland many of the frontline workers in senior care homes, farms, or food processing plants were people with precarious status, notably seasonal migrants, asylum seekers waiting for their application to be processed, or mere sojourners without the right to work. They performed their 'citizenship duty' even if they had no secure legal status and did not belong to the community. Indeed, this argument sparked a controversy in Quebec, Canada, in June 2020 when asylum seekers employed in senior care homes - which were hard hit by 
the pandemic - mobilised, asking to obtain permanent residency status as a recognition of their contribution to the safety and care of community members (Levitz \& Kestler d'Amours, 2020). The Prime Minister of the province refused but after further negotiations with the federal government, a special path to permanent residency was announced by the federal minister, Marco Mendicino, on 14 August 2020. Minister Mendicino explained the decision by reflecting on the fact that these asylum seekers put themselves at risk day after day on the pandemic and 'they demonstrated a uniquely Canadian quality' (argued Mendicino) 'in that they were looking out for others and so that is why today is so special' (Seidle, 2020).

On the other hand, several citizens have been found in breach of their civic duty to follow government guidance, for instance, to not travel across regions. Maria (the name is fictitious), originating from Sicily and studying in Milan, in early March 2020 travelled home to Palermo as Lombardy became a 'red zone' and moving in or out of the region was forbidden. Upon arrival, she visited her grandfather at a seniors' home in the region. Five days later Maria developed symptoms of Covid-19. The facility was quarantined and over one hundred people, including staff and seniors, were directly affected, some died. Maria did not travel across international borders and is a citizen of Italy. But her behaviour was not in line with the notion of loyalty and solidarity towards her fellow citizens, even if inadvertently. And, of course, she was not the only one. During the fall of 2020 we have witnessed a rise of Covid deniers and mask protesters rallying across Europe and North America while young people partying without masks have been advocating their right for fun since they are less susceptible to suffering severely from the illness.

The pandemic has thus highlighted important contradictions between the status of citizen/permanent resident and the ways in which one acts in a civically responsible way, protecting fellow citizens with their behaviour (or indeed exposing them to risks). The question that arises and is discussed in some of this book's chapters is the extent to which these new insights can become codified in migration and citizenship law (see for instance Macklin Chap. 2, in this volume). This brings me to the second set of questions that the pandemic has raised in relation to migration governance which I will tackle in the following section.

\subsection{Selective Openings and Closures: Essential Work and Frontline Migrant Workers}

Under the emergency, specific categories of workers (which include migrant workers) have been characterised as 'essential' - vital for the economy and the community's well-being (see Macklin, also Gahwi and Walton-Roberts Chap. 6, in this volume). These have included medical and paramedical personnel, care workers but also farm labourers and people working in the food processing industry. These workers have not only been essential but also vulnerable as the sectors they work in and the conditions under which they work put them at risk of contracting the virus. 
As borders closed and immigration came to a halt across Europe and North America, farmworkers have been exempted from such restrictions and were even brought to destination on chartered flights from Mexico to Canada and from Romania to Germany for instance.

Governments in Canada and Germany but also Italy, Spain, and Poland mobilised (see also Palumbo and Corrado Chap. 8, in this volume) to find appropriate solutions for bringing in migrant workers for agriculture, including chartered flights with few passengers sitting at a safe 'distance', assistance to employers for the quarantine period in appropriate accommodation, and self-isolation. However, these measures had less to do with a new sensitivity about the living or working conditions of these temporary foreign workers. Rather, they were a knee-jerk reaction to the fear of the agriculture and food processing sectors' production chain breaking down, leaving supermarkets in short supply and harvests wasted (Nalbandian \& Triandafyllidou, 2020b). The concern was also to protect the local community from contagion and a possible outbreak if a migrant worker tested positive for Covid-19. Indeed, the safety measures and monitoring and support only extended through the quarantine period. After it was lifted, there was little follow-up or protection for the migrant workers (Migrant Workers Alliance for Change, 2020), who were often returned to crowded accommodation or given protective equipment when their work did not allow for physical distancing. The meat industry in several European countries, the US, and Canada emerged as a pandemic hotspot (Palumbo \& Corrado, 2020a). Similar challenges were faced by care workers in private homes under the pandemic (Caregivers Action Centre, 2020; Marchetti \& Boris, 2020) who were confronted with restriction of their freedom, laid off without notice, and often risked irregular status and expulsion because they were found to be in breach of their stay permit through no fault of their own.

These exemptions from border restrictions for essential workers and the related challenges that ensued in terms of protection from the virus but also from severe exploitation are common across North America and Europe (Palumbo \& Corrado, 2020b; Triandafyllidou \& Nalbandian, 2020). The agri-food sector hit the headlines in the summer of 2020 because of concerns about the food supply chain but also in recognition of the difficult working and living conditions in the sector. Agriculture is characterised by demanding working conditions, low prestige, and low pay, where work is mainly seasonal and requires a supply-and-demand mechanism that is ultraflexible. Workers must be available on call and can be easily dismissed. At the same time, as Corrado and co-authors (2018) have argued, today's agriculture is characterised by intensive pressures to keep production costs low. Large corporations in the retail and agri-food sectors push for low prices to maximise benefits and, given the large volume of products that they can absorb, can impose their conditions on producers. Producers are faced with irreducible costs, like the increasing need to invest in automation, the cost of water and energy for production, and the cost of fertiliser, seeds, and feed. Thus, squeezing labour costs through employing migrants with precarious status appears almost an inevitable choice, particularly for smaller producers. The structure of the network among commercial chains, agroentrepreneurs, intermediaries, and the final consumers pushes for lower prices for 
fruits and vegetables and with difficult traceability of products (Corrado et al., 2018). Employment dynamics in agriculture are thus shaped by several factors that include but are not confined to migrant labour. Rather they have more to do with agricultural policy, the structure of the agricultural and food processing sectors, and the limited controls over oligopolistic tendencies in national markets.

Similar challenges have been registered in the care sector particularly when it comes to care for seniors. The demand in European countries remains high; the population is aging and its care needs rising but there is as yet no viable plan for catering to these needs. The pandemic has exposed labour shortages in the sector and vulnerabilities of workers in terms of precarious status (temporary or indeed undocumented), difficult and often substandard working conditions, lack of access to fundamental rights and support by non-governmental organisations or government agencies that already existed (see also Triandafyllidou \& Marchetti, 2015; Triandafyllidou, 2013). These vulnerabilities have been exacerbated by the pandemic and have exposed important care gaps across North America and Europe (see Gahwi and Walton Roberts, also Rosińska and Pellerito Chap. 7, in this volume; Rogalewski, 2020; EFFAT, 2020).

However, a crisis such as this can tip the balance and put in motion a mechanism for change. Several policy initiatives were taken in both the agriculture and care sectors in the last few months by different countries in the effort to address these challenges. On 15 May 2020, the Canadian government introduced the Agri-food Immigration Pilot where migrant workers in agriculture could apply for permanent residency. Unfortunately, the programme - criticised for being inaccessible as it requires equivalency of secondary education diploma in Canada and relatively high proficiency in English language - foresees only 2750 applicants and family members and expires on 14 May 2023. There have been however important policy discussions on how to improve the pathway of seasonal workers to permanent residency and on combining this pilot with the Municipal Nominee pilot that Canada is also about to launch, whereby mid-sized cities would be able to invite new immigrants (Alboim \& Kohl, 2020).

On 14 May 2020, Italy implemented a regularisation programme, addressing farmworkers and domestic and care workers in private homes. When the deadline expired at the end of August 2020, 207,000 migrant workers and their employers had submitted their applications under this programme, of which 176,000 were domestic workers (Ministero del Lavoro, 2020). It is estimated that these applicants cover only a portion of the undocumented migrant worker population in these sectors, particularly in agriculture where applications were comparatively few (Bonifazi $\&$ Strozza, 2020). There is no doubt that this will provide for a significant improvement in the livelihoods of a large number of people even though it may not fully address the exploitative working conditions that migrant workers in these sectors face (Zanfrini, 2020). In contrast to the solutions offered by Italy or Canada, in the US the debate is yet to re-emerge even though the US Department of Labor National Agricultural Workers' Survey documents that approximately $47 \%$ of the roughly 2.4 million farmworkers in the US are undocumented. A bill providing two-step 
access to legal status and then citizenship was introduced in Congress in January 2019 but has stalled since March of the same year.

The pandemic has kickstarted important policy discussions on how agricultural or welfare policy, on one hand, and migration policy, on the other, can work in tandem to address labour market shortages while offering secure status and rights to workers. Unlike in the past, current studies have focused on a medium- to long-term perspective and on both the economic and social sustainability of the relevant sectors (see also Gahwi and Walton Roberts Chap. 6, in this volume; Fasani \& Mazza, 2020; EMN, 2020b). Reports focusing on migrants in rural areas have been looking into regional and sectoral distributions, levels of skills, and employers' concerns (Kalantaryan et al., 2020; Baiocco et al., 2019). The question that arises of course is how this initial positive reaction and drive towards innovation and sustainability can translate into more lasting changes and whether there is political will to address structural issues such as the protection of labour rights and particularly the rights of migrant workers. On this front the lessons learnt from the EU refugee emergency of 2015-2016, the initial positive policy innovations like the emergency resettlement quotas and the calls for reforming the Dublin system, have been significantly watered down in subsequent years, leading to a much less ambitious EU pact on migration and asylum (European Commission, 2020; Beirens, 2020). The pandemic though has fuelled a transnational policy debate on how to address imbalances and shortages in these sectors, pushing the emphasis away from immigration and into the specific employment and service sectors.

The question that arises at both the analytical and policy levels is whether the global migration governance institutions and tools at our disposal are fit for this purpose. The advantages and limitations of the global governance of migration have been extensively discussed for the last 20 years (Betts, 2010; Koser, 2010). However, a crisis of forced immobility rather than migration such as the one caused by the pandemic is unprecedented. The newest tools in our global governance palette, notably the Global Compacts, were designed for a hyper-mobile not an immobile world. Nonetheless, several of its key objectives are still relevant and can provide a path towards reopening, such as reducing vulnerabilities during migration, strengthening consular services, using detention only as a last resort, and providing migrants with access to basic services such as healthcare (Newland, 2020). The calls for action included in the Global Compact for Migration (2018) on coordinated border management, on providing predictable procedures for migration screening and assessment in order to refer migrants to appropriate channels for admission, and on providing adequate documentation to all migrants are all issues that are still relevant as countries prepare to reopen after the pandemic. The situation on the ground for returning or stranded migrants is particularly challenging (see also Sahin Mencutek and Rajan and Arokkiaraj Chap. 11, in this volume). The need to address this situation and the limited capacity of origin countries to deal with reduced remittances and massive returns remains of course a challenge for both domestic and regional migration governance (Shivakoti, 2020). 


\subsection{The Contents of this Volume}

Contributions to this volume discuss theoretical and policy challenges that the pandemic crisis has posed to international migration. The first part of this book focuses on the analytical and normative questions that pertain to the management of the pandemic emergency and the governance of migration and asylum, while the second part focuses on specific categories of migrants that face the most acute challenges in relation to the pandemic.

In Chap. 2 Audrey Macklin discusses the notion of essential work or essential workers. Macklin focuses on those exceptions to the border closures and the ways in which they were justified and legitimised. She shows how the category of "essential' was produced, revised, and represented through the interaction of pandemicdriven exigencies and nationally-specific legal, political, and economic constraints. To understand how the admission into Canada of certain people was accepted as legally, economically, and/or politically essential, argues Macklin, one must take account of Canada's character as a settler society, its economic integration with the US, and its growing dependence on migrant workers and international students to subsidise food production and higher education for nationals. Her argument however has a general valence as these different dimensions of being economically, politically, or legally essential have dominated policy decisions in many countries around the world.

Addressing the pandemic has brought a new interest to the use of technology for contact tracing and indirectly hence for surveillance of people's movements and contacts in the interest of public health. Petra Molnar, in Chap. 3, discusses how we can learn from previous experiments of bio-surveillance implemented on migrant and refugee populations, and also warns against an enthusiastic embrace of such technologies. Molnar argues that such technological experiments on people on the move (particularly refugees) have been shown to breach privacy and endanger lives. Algorithms used to power this technology are vulnerable to the same decisionmaking of concern to humans: discrimination, bias, and error. Unfortunately, little regulation exists to govern technological experimentation. Virus-killing robots, cellphone tracking, and artificially intelligent thermal cameras can all be used against people crossing borders with far-reaching results and impacts on various human rights. The pandemic offers both a risk but also an opportunity to rethink the way in which technology can be used to support rather than surveil vulnerable populations on the move.

In Chap. 4 Eileen Boris focuses on structures of systemic racism and precarity that compound the vulnerability of undocumented, transgender, and gender nonconforming individuals and those from racially othered group under the pandemic. Women among them have found new difficulties in meeting double obligations: to earn a living and care for households, both family requiring daily tending and those dependent on remittances sent back to countries of origin. Especially among migrants labelled as 'essential workers', the lack of protective equipment and labour rights has put them on the frontline of exposure. But domestic and home care 
workers, meat packers, field hands, and others have stepped out of the shadows to demand inclusion in social assistance, occupational health and safety laws, and other state benefits. They have not relied on the state alone; rather, they have developed mutual aid and coalitional activism to advance their dignity and improve living as well as working conditions. With a focus on the US, for over two centuries a major destination for migrants, this chapter historicises the recent hardships and the organizing of migrant workers.

Turning to the local level, Chap. 5 by Mireille Paquet, Noémie Benoit, Idil Atak, Meghan Joy, Graham Hudson, and John Shields looks at urban centres that have been especially hit by the Covid-19 pandemic, with a special focus on non-status and precarious migrants. Using official data and published research, this chapter explores how city sanctuary policies in Canada have addressed these pandemic risks. The chapter highlights the specificities of sanctuary policies in the Canadian context and documents that while cities have not rescinded these interventions during the pandemic, they also have not built on them when developing services for urban residents. The chapter discusses how the pandemic interacts with the multilevel governance of migration and migrant integration and explores whether this crisis can be a lever for reform, increasing cities' resources and capacities to implement and institutionalize policies for non-status and precarious migrants.

In the second part of this volume, Lena Gahwi and Margaret Walton-Roberts (Chap. 6) review the impending global care crisis in terms of the quantity of care needed for an aging population and the quality of both the care provided and conditions of work for those who provide this care. Through a critical comparative overview, this chapter points to the imbalances characterising long-term care provision and the type and skill mix of labour, including the degree to which immigrant workers are over-represented in this sector. The chapter offers conceptual reflections on elder care as a matter of social justice and ethics in terms of those needing and providing care. These ethical and social justice concerns take on a specific global dimension as care has been transnationalised through migration and global care chains. Looking at different funding models for long-term care and taking into account the pressures that the pandemic has put on an already strained system, the chapter highlights the gendered and racialised devaluing of migrant labour so essential to the sector and the importance of effecting crucial reforms.

Chapter 7 by Anna Rosińska and Elizabeth Pellerito focuses on the case of domestic and care workers employed in private households and discusses the risks and vulnerabilities they face. During the current global pandemic, when the family or household has been considered the most basic unit of quarantine, the role of the domestic worker - someone who by definition crosses the threshold and enters the space of the home - became problematised quickly. Some tasks like elder care, childcare, and personal or disability care have become more important than ever at a time when few could access social services in person and institutions like care homes were the source of major outbreaks. On the other hand, the 'outsider' status of these workers - transgressing the boundaries not just of the physical household space, but often also of race, immigration status, and class - has meant that some service workers were more readily regarded as disease vectors who were too risky 
to allow into the home and let go with little or no warning. State responses to the pandemic in the US have included stay-at-home orders that differentiate between essential and non-essential businesses; shifting immigration regulations; and federal and state relief bills, many of which continue to exclude the sector as a whole and undocumented immigrant workers from accessing relief measures. Overall, domestic workers were confronted with the impossible choice between isolating with the families they worked for so as not to put their own families at risk or losing their jobs and forfeiting access to state-provided benefits and relief systems. This chapter uses online ethnography of organisations, an online survey for domestic workers, and outreach work within the labour and workers' rights movement to analyse the multilevel response of domestic workers' organisations to address the crisis. Organisations, especially worker centers, doubled their efforts to absorb part of the pandemic shock. These responses span from initiatives addressed at immediate financial and material relief for individual workers to continued policy advocacy at the federal and state levels for broad-based protections like hazard pay, health and safety regulations, or eviction moratoria.

Chapter 8 by Letizia Palumbo and Alessandra Corrado focuses on the muchdiscussed agriculture sector and the shortages and challenges that the pandemic had caused already by spring 2020. Border lockdowns have immobilised thousands of foreign seasonal workers at their countries of origin, prompting fear of labour shortages and food production losses in Europe and North America. While over the last 30 years migrant farmworkers have become a fundamental component of core sectors such as the agri-food sector, it is only in the current health emergency that these have been clearly recognised as essential workers, as the need arises to address food security. Palumbo and Corrado investigate the working conditions of migrant farmworkers alongside national debates and institutional interventions in Italy and Spain during the Covid-19 crisis. The chapter provides a critical comparative analysis of the legal and policy interventions adopted to address migrants' condition of vulnerability. Both countries count on important contingents of EU and non-EU migrant farmworkers, especially in the production of fruit and vegetables. Moreover, they present common aspects regarding supply chain dynamics and labour market policies, but also some specific differences with respect to labour migration and social policies. Both countries have adopted actions to address the condition of irregularity of migrants during the pandemic. However, despite the enthusiastic and optimistic tones from the general public, these interventions reveal shortcomings that significantly limit their impact and outcomes. This calls into question the extent to which migrant workers are really considered 'essential' on a long-term perspective and, therefore, to what extent the current pandemic constitutes an opportunity for a new national push to enforce labour and migrant rights.

International students are a less discussed but significantly vulnerable population under the pandemic emergency. International students were not included in most migration debates because they were seen as temporary sojourners, moving for a few months or years and then transitioning back, either to the countries from which they came or changing their status into workers. However, the coronavirus pandemic has exposed both the essential and constitutive nature of international 
students to higher education. In Chap. 9, Parvati Raghuram and Gunjan Sondhi demonstrate that they constitute an important part of export earnings in some of the major receiving countries, contribute to subsidising the university sectors and the local economy through their expenditure on housing and consumer goods as well as their work in selected industries. Crucially, they also play an important part in knowledge production and circulation - the core business of higher education. They are thus an important part of the very fabric of higher education. These issues have come to a head during the pandemic as mobilities are interrupted and education reshaped. The coronavirus emergency has starkly exposed this financial dependence that higher education sector has on high fee-paying international students. This chapter explores the issues that international students have faced and the impact of suspended mobilities on the sector and draws out the conceptual implications of inserting students into migration research on the pandemic.

One of the most important impacts of the pandemic as regards international migration has been that of forcing hundreds of thousands of migrants to return, totally unexpectedly and without any preparation. It was not only visitors and tourists who were obliged to return to their place of origin but also internal and international migrants who lost their jobs nearly overnight. Migrants' decisions have been marked by deep impasses between staying and return. Against this background, Chap. 10 by Zeynep Sahin Mencutek addresses the following questions: how and to what extent did the pandemic trigger the returns of migrants? What were the diverging characteristics of returning compared to other crisis-situations and before pandemic times? How do receiving and sending countries respond to returns? How has the pandemic influenced migrants' aspirations about staying and returning? These questions enable reconsidering the highly contested concepts of return migration scholarship such as voluntary versus forced returns (including deportations and removals); sustainable versus unsustainable returns; permanent versus temporary returns.

Chapter 11 by S Irudaya Rajan and H. Arokkiaraj further explores the question of return migration from the Gulf countries. Most of the affected workers are bluecollar, largely employed as temporary workers in construction and allied sectors. As per the Ministry of External Affairs (India) statistics, 2.5 million Indians have gone abroad for employment in 2019 alone. Among the migrants from India, countries in the Gulf have historically been the most-favoured destinations for job roles in the construction sector. However, the pandemic crisis halted construction projects in the Gulf. Furthermore, a drastic drop in oil prices has affected Gulf oil and non-oil economies severely. This has had an adverse effect on Indian construction workers in Gulf as they face the threat of unemployment, leading to their voluntary or forced return to India. For example, as of December 2020, 61,009 Kerala emigrants, most of them in the Gulf, have lost their jobs abroad due to the pandemic, making their return inevitable given their already temporary status in these countries. Against this background, this chapter examines a broad research question-how is India prepared to handle the changing trends in the Indo-Gulf migration corridor and the subsequent return emigration from the Gulf? This chapter highlights the perspectives of individual major sending states, such as Kerala and others, and their 
responses towards Gulf returnees. Moreover, it provides insights by revisiting the existing economic and social security for the return migrants and their families within the framework of state welfare schemes, thereby examining rehabilitation and re-integration mechanisms for return migrants at the central and state levels in India.

Last but not least, Chap. 12 by S Irudaya Rajan and R. B. Bhagat examines the effect of the Covid-19 pandemic on internal migrants in India. According to the 2011 Census, there are over 450 million internal migrants in India, of which a massive 54 million constitute inter-state migrants. In addition, India also has 85 million intra-state (within the state) migrants. These migrants largely consist of casual labourers who comprise a huge percentage of the informal sector workforce, in both rural and urban areas of India, and are vital to the country's economy. These workers are also some of the most vulnerable sections of India's labour force, with inadequate coverage in terms of working conditions and social safety nets, and are also largely absent from India's policy discourses. However, the pandemic brought their precarity to the focus of the entire nation as, confronted with unemployment and destitution during a 54-day national lockdown, many migrants were forced to leave their places of work en masse, often in inhospitable conditions, to make their way home. This chapter thus highlights the size and extent of internal migration in India as well as its distribution across different states in India and how the covid-19 crisis and lockdown affected their lives and livelihoods. It particularly looks at the responses of central and various state governments - at the destinations, origins, and even places of transit where migrants have been stranded - to ensure migrants' wellbeing. The chapter also analyses the economic impact of the migrant exodus from major destinations and how that will affect migration patterns and policy in India in the future.

\section{References}

Abji, S., Pintin-Perez, M., \& Bhuyan, R. (2020). In Canada, non-status women are being left behind. Open Democracy. https://www.opendemocracy.net/en/pandemic-border/canada-nonstatus-women-are-being-left-behind/. Accessed 28 Feb 2021.

Alboim, N., \& Kohl, C. (2020, October 26). More agricultural workers should become permanent residents. Policy Options. https://policyoptions.irpp.org/magazines/october-2020/moreagricultural-workers-should-become-permanent-residents/. Accessed 28 Feb 2021.

Aleinikoff, A. T. (1995). The Tightening Circle of Membership, 22 Hastings Const. L.Q. 915 (1995). Available at: https://repository.uchastings.edu/hastings_constitutional_law_quaterly/ vol22/iss $4 / 1$.

Baiocco, S., Busse, M., Cirule, E., Di Salvo, M., \& Lenaerts, K. (2019, May 15). Labour costs in agriculture: comparative study, VS/2017/0371, prepared on behalf of GEOPA-COPA.

Baubock, R. (Ed.). (2018). Debating transformations of national citizenship. Springer. https:// www.springer.com/gp/book/9783319927183. Open Access.

Bauböck, R. (Ed.). (2019). Debating European Citizenship. Springer, https://www.springer.com/ gp/book/9783319899046 
Beirens, H. (2020). The EU pact on migration and Asylum-A bold move to avoid the Abyss? https://www.migrationpolicy.org/news/eu-pact-migration-asylum-bold-move-avoid-abyss

Betts, A. (Ed.). (2010). Global Migration Governance. Oxford University Press.

Bonifazi, C., \& Strozza, S. (2020). La nuova regolarizzazione: criteri e domande presentate. https://www.neodemos.info/2020/09/22/un-primo-bilancio-della-regolarizzazione/

Caregivers Action Centre. (2020, October). Behind Closed Doors. Exposing Migrant Care Worker Exploitation under Covid-19. Report online: www.MigrantRights.ca/BehindClosedDoors https://migrantrights.ca/wp-content/uploads/2020/10/Behind-Closed-Doors_ExposingMigrant-Care-Worker-Exploitation-During-COVID19.pdf

Canadian Charter of Rights and Freedoms. (1982). https://laws-lois.justice.gc.ca/eng/const/ page-15.html.

Corrado, A., Nori, M., Palumbo, L., Caruso, F., \& Lo Cascio, M. (2018, November). Is Italian agriculture a 'pull factor' for irregular migration - and, if so, why? Technical report, EUI and Open Society Foundations.

EFFAT. (2020). EFFAT - EFFE - EFSI - UNI-Europa Joint Statement on the COVID-19 Pandemic in Personal and Household Services (PHS), supported by IDWF (International Domestic Workers Federation) https://www.uni-europa.org/wp-content/uploads/2020/04/EFFAT-EFFEEFSI-UNI-Europa-Joint-Statement-COVID-19-Pandemic-in-PHS-EN.pdf

Ellis, C. (2020). COVID-19: Canada locks its gates to asylum seekers. https://www.opendemocracy.net/en/pandemic-border/covid-19-canada-locks-its-gates-asylum-seekers/.

EU Charter of Fundamental Rights. (2012). https://ec.europa.eu/info/aid-development-cooperationfundamental-rights/your-rights-eu/eu-charter-fundamental-rights_en.

European Commission. (2020). Communication from the Commission to the European Parliament, the Council, the European Economic and Social Committee and the Committee of the Regions, on a New Pact on Migration and Asylum, Brussels, 23.9.2020, COM(2020) 609 final.

European Migration Network. (2020a). Inform \#1 Eu and OECD member states responses to managing residence permits and migrant unemployment during the Covid-19 pandemic.

European Migration Network. (2020b). Inform \#3 Maintaining labour migration in essential sectors in times of pandemic.

Fasani, F., \& Mazza, J. (2020). Immigrant key workers: Their contribution to Europe's COVID-19 Response (IZA Policy Paper No. 155). IZA.

Flynn, M., \& Welsford, K. (2020). COVID-19 reveals the inherent vindictiveness of migration detention. Open Democracy. https://www.opendemocracy.net/en/pandemic-border/covid-19reveals-inherent-vindictiveness-migration-detention/. Accessed 28 Feb 2021.

George, U. (2020). Will Canada give its foreign essential workers their rights? Open Democracy. https://www.opendemocracy.net/en/pandemic-border/will-canada-give-its-foreign-essentialworkers-their-rights/. Accessed 28 Feb 2021.

Global Compact for Migration. (2018). https://www.iom.int/global-compact-migration

Godoy, M., \& Bauder, H. (2020). What can we learn from Latin America's solidarity cities? Open Democracy. https://www.opendemocracy.net/en/pandemic-border/what-can-we-learn-fromlatin-americas-solidarity-cities/. Accessed 28 Feb 2021.

Humphreys, S. (2006). Legalizing Lawlessness: On Giorgio Agamben's State of Exception. The European Journal of International Law, 17(3), 677-687. https://doi.org/10.1093/ejil/chl020

Jubilut, L., \& Silva, J. C. (2020). COVID-19 at the Brazil-Venezuela borders: The good, the bad and the ugly. Open Democracy. https://www.opendemocracy.net/en/pandemic-border/ covid-19-brazil-venezuela-borders-good-bad-and-ugly/. Accessed 28 Feb 2021.

Kalantaryan, S., Mazza, J., \& Scipioni, M. (2020). Meeting labour demand in agriculture in times of COVID 19 pandemic. Joint Research Centre of the European Commission, JRC120800.

Koser, K. (2010). Introduction: International migration and global governance. Global Governance, 16(3), 301-315. http://www.jstor.org/stable/29764947. Accessed 6 Nov 2020.

Levitz, S., \& Kestler d'Amours, J. (2020, August 14). Asylum seekers on front lines of COVID-19 to have chance at permanent residency. The Canadian Press. https://www.cp24.com/news/asylum- 
seekers-on-front-lines-of-covid-19-to-have-chance-at-permanent-residency-1.5064978. Accessed 12 Jan 2021.

Marchetti, S., \& Boris, E. (2020). Migrant domestic and care workers: high risk but low protection. Open Democracy. https://www.opendemocracy.net/en/pandemic-border/migrant-domesticand-care-workers-high-risk-low-protection/. Accessed 28 Feb 2021.

Migrant Workers Alliance for Change. (2020). Unheeded warnings: Covid-19 and migrant workers in Canada. https://migrantworkersalliance.org/wp-content/uploads/2020/06/UnheededWarnings-COVID19-and-Migrant-Workers.pdf. Accessed 28 Feb 2021.

Ministero del Lavoro. (2020). Emersione dei rapporti di lavoro (Regularisation of labour relations) https://www.interno.gov.it/sites/default/files/2020-08/dlci_-_analisi_dati_emersione_15082020_ore_24.pdf. Accessed 30 Nov 2020.

Molho, J. (2020). Will the 'Singapore model' survive the pandemic? Open Democracy. https:// www.opendemocracy.net/en/pandemic-border/will-the-singapore-model-survive-thepandemic/. Accessed 28 Feb 2021.

Molnar, P., \& Braam, D. (2020). Refugees at increased risk of coronavirus due to barriers to healthcare. The Conversation. https://theconversation.com/refugees-at-increased-risk-ofcoronavirus-due-to-barriers-to-healthcare-137217. Accessed 28 Feb 2021.

Nalbandian, L., \& Triandafyllidou, A. (2020a, June 11). Can the COVID-19 crisis be an opportunity for Canada's migrant farmworkers? First Policy Response.

Nalbandian, L., \& Triandafyllidou, A. (2020b, June 10). High-skilled immigrants are stuck in limbo. Can we help them 'work remotely?'. First Policy Response.

Newland, K. (2020). Will International Migration Governance Survive the COVID-19 Pandemic? Migration Policy Institute. https://www.migrationpolicy.org/research/international-migrationgovernance-covid-19-pandemic. Accessed 28 Feb 2021.

Palumbo, L., \& Corrado, A. (2020a). Covid-19, Agri-food systems, and Migrant Labour. The situation in Germany, Italy, The Netherlands, Spain and Sweden, Brussels. Open Society Foundations. https://www.opensocietyfoundations.org/uploads/ccf241cc-89b2-4b44-a59590bd77edab3d/covid19-agrifood-systems-and-migrant-labour-20200715.pdf. Accessed 28 Feb 2021.

Palumbo, L, \& Corrado, A. (2020b). Keeping the Italian agri-food system alive: Migrant farmworkers wanted! Open Democracy. https://www.opendemocracy.net/en/pandemic-border/ keeping-italian-agri-food-system-alive-migrant-farmworkers-wanted/. Accessed 28 Feb 2021.

Petcharamasree, S. (2020). COVID-19 in Southeast Asia: non-citizens have a right to protection too. Open Democracy. https://www.opendemocracy.net/en/pandemic-border/covid-19southeast-asia-non-citizens-have-right-protection-too/. Accessed 28 Feb 2021.

Pinelli, B. (2018). Control and abandonment: The power of surveillance on refugees in Italy, during and after the Mare Nostrum operation. Antipode, 50(3), 725-747. https://doi.org/10.1111/ anti. 12374

Raghuram, P., \& Sondhi, G. (2020). Stuck in the middle of a pandemic: Are international students migrants? Open Democracy. https://www.opendemocracy.net/en/pandemic-border/stuckmiddle-pandemic-are-international-students-migrants/. Accessed 28 Feb 2021.

Rogalewski, A. (2020). Live-in care sector needs EU policies to protect it, more than ever. Euractiv. https://www.euractiv.com/section/all/opinion/live-in-care-sector-needs-eu-policies-to-protectit-more-than-ever/. Accessed 28 Feb 2021.

Romero, V. C. (1998). Expanding the circle of membership by reconstructing the 'Alien': Lessons from social psychology and the 'Promise Enforcement' Cases, 32 U. MICH. J. L. REFORM 1. Available at: https://repository.law.umich.edu/mjlr/vol32/iss $1 / 2$

Rugunanan, P. (2020). 'South Africa belongs to all who live in it', COVID-19 showed it does not. Open Democracy. https://www.opendemocracy.net/en/pandemic-border/south-africa-belongsto-all-who-live-in-it-covid-19-showed-it-does-not/. Accessed 28 Feb 2021.

Seidle, L. (2020, May 26). Issue 41: Should Canada regularize the immigration status of asylum seekers helping fight COVID-19? https://maxpolicy.substack.com/p/issue-41-should-canadaregularize. Accessed 12 Jan 2021. 
Shakuto, S., \& Baldari, F. (2020). Japan's migrants are not allowed to go 'home'. Open Democracy. https://www.opendemocracy.net/en/pandemic-border/japans-migrants-are-not-allowed-to-gohome/. Accessed 28 Feb 2021.

Shivakoti, R. (2020). Can Nepal cope with the return of migrant workers? Open Democracy. https://www.opendemocracy.net/en/pandemic-border/can-nepal-cope-return-migrantworkers/. Accessed 28 Feb 2021.

Stavilă, A. (2013). Citizens-minus and Citizens-plus: A normative attempt to defend citizenship acquisition as an entitlement based on residence. European University Institute.

Triandafyllidou, A. (2013). Irregular migrant domestic workers in Europe: Who cares? Ashgate.

Triandafyllidou, A., \& Nalbandian, L. (2020, July). 'Disposable' and 'essential': Changes in the global hierarchies of migrant workers after COVID-19. IOM Policy Brief. https://publications. iom.int/books/covid-19-and-transformation-migration-and-mobility-globally-disposable-andessential-changes

Triandafyllidou, A., \& Veikou, M. (2002). The hierarchy of Greekness. Ethnic and national identity considerations in Greek Immigration Policy. Ethnicities, 2(2), 189-208.

Triandafyllidou, A., \& Marchetti, S. (Eds.). (2015). Employers, agencies and immigration: Paying for care. Ashgate.

Wright, R. (2020). Vulnerable and unprotected in the US: It only takes political will. Open Democracy. https://www.opendemocracy.net/en/pandemic-border/vulnerable-andunprotected-us-it-only-takes-political-will/. Accessed 28 Feb 2021.

Zanfrini, L. (2020, April 29). Regolarizzare gli immigrati perché è giusto, non perché conviene. Italy, Huffington Post. Available at: https://www.huffingtonpost.it/entry/regolarizzare-gliimmigrati-perche-e-giusto-non-perche-conviene_it_5ea992fac5b6fb98a2b61f8c. Accessed 25 Aug 2021.

Open Access This chapter is licensed under the terms of the Creative Commons Attribution 4.0 International License (http://creativecommons.org/licenses/by/4.0/), which permits use, sharing, adaptation, distribution and reproduction in any medium or format, as long as you give appropriate credit to the original author(s) and the source, provide a link to the Creative Commons license and indicate if changes were made.

The images or other third party material in this chapter are included in the chapter's Creative Commons license, unless indicated otherwise in a credit line to the material. If material is not included in the chapter's Creative Commons license and your intended use is not permitted by statutory regulation or exceeds the permitted use, you will need to obtain permission directly from the copyright holder. 